\title{
PENGARUH BUDAYA ORGANISASI TERHADAP KEPUASAN KERJA KARYAWAN PADA JASA PERHOTELAN (Studi Kasus di Garuda Plaza Hotel Medan)
}

\author{
Effendi Sinuhaji \\ Program studi Manajemen Perusahaan, STIM Sukma Medan \\ Telp. 061-7334455 \\ email: effendy_aji@yahoo.com
}

\begin{abstract}
ABSTRAK
Tujuan penelitian ini adalah untuk mengetahui pengaruh Pengaruh Budaya Organisasi terhadap Kepuasan Kerja Karyawan pada Jasa Perhotelan. Penelitian dilakukan terhadap 61 orang karyawan yang menjadi responden penelitian, metode analisis yang digunakan menggunakan metode analisis statistik deskriptif dengan korelasi product moment. Hasil penelitian menunjukkan bahwa budaya organisasi berpengaruh terhadap kepuasan kerja karyawan.
\end{abstract}

Keyword: Budaya organisasi dan kepuasan kerja.

\section{PENDAHULUAN}

Orgnaisasi merupakan suatu persekutuan antara dua orang atau lebih yang bekerja sama untuk mencapai tujuan yang telah ditetapkan. Tonggak keberhasilan organisasi terletak kepada pihak manajemennya yang mempunyai wawasan yang luas. Bagaimanapun tanpa pegawai dan atasan yang mengamalkan budaya organisasi cemerlang akan menghambat usaha untuk menghasilkan tujuan organisasi. Permasalahan budaya dalam organisasi (budaya organisasi), khususnya selama dua dasawarsa terakhir ini telah menjadi fokus perhatian masyarakat luas, seperti yang terlihat pada banyak literatur yang membahas topik ini. Ketertarikan terhadap budaya organisasi ini dikarenakan budaya organisasi dipercaya turut menentukan maju atau mundurnya bisnis sebuah perusahaan.

Budaya organisasi dalam sebuah organisasi biasanya dikaitkan dengan nilai, norma, sikap dan etika kerja yang dpegang bersama oleh setiap komponen organisasi. Empat unsur ini menjadi asas untuk mengawasi perilaku pegawai, cara mereka berfikir, bekerja sama dan berinteraksi dengan lingkungannya. Jika budaya organisasi ini baik, maka akan dapat meningkatkan kepuasan kerja yang tinggi dan akan menyumbangkan keberhasilan kepada perusahaan Budaya organisasi merupakan sistem penyebaran kepercayaan dan nilai-nilai yang berkembang dalam suatu organisasi dan mengarahkan perilaku anggota-anggotanya. Budaya organisasi dapat menjadi instrumen keunggulan kompetitif yang utama, yaitu bila budaya organisasi mendukung strategi organisasi, dan bila buadaya organisasi dapat menjawab atau mengatasi tantangan lingkungan dengan cepat dan tepat. budaya organisasi selain berpengaruh terhadap kepuasan kerja. sElanjutnya kepuasan kerja karyawan berpengaruh terhadap kinerja pegawai. Kepuasan kerja pegawai yang tinggi merupakan salah satu indekator juga efektivitas manajemen, yang berarti bahwa budaya organisasi telah dikelola dengan baik.

\section{TINJAUAN}

Budaya organisasi berkaitan dengan bagaimana karyawan mempersepsikan karakteristik dari budaya suatu organisasi, bukannya dengan apa mereka menyukai budaya itu atau tidak. Artinya, budaya itu merupakan suatu istilah deskriptif. Budaya organisasi merupakan suatu persepsi bersama yang dianut oleh semua anggota organisasi. Untuk lebih jelasnya pengeryian budaya organisasi berikut ini akan dikemukakan pendapat beberapa ahli Perilaku organisasi, diantaranya : Menurut Kreitner dan Kinicki (2003) menyatakan bahwa :Budaya organisasi adalah salah satu wujud anggapan yang demikian, terima secara imlisit oleh kelompok dan menentukan bagaimana kelompok tersebut rasakan, pikiran dan bereaksi terhadap lingkungannya yang beraneka ragam.

Selanjutnya David (2004) menyatakan yaitu : Budaya organisasi adalah pola tingkah laku yang dikembangkan oleh suatu organisasi yang dipelajarinya ketika menghadapi masalah adaptasi eksternal dan integrasi internal, yang telah terbukti cukup baik untuk disahkan dan diajarakan kepada anggota baru sebagai cara untuk menyadari, berpikir dan merasa. Robbins (2001) menyatakan riset paling baru mengemukakan tujuh karakteristik primer yang bersama-sama menangkap hakikat dari suatu budaya suatu organisasi yaitu : 
1. Inovasi dan pengambilan resiko, sejauhmana karyawan didorang untuk inovatif dan mengambil resiko

2. Perhatian, sejauhmana karyawan diharapkan memperlihatkan presisi, analissis dan perhatian kepada rincian.

3. Orientasi orang, sejauhmana keputusan manajemen memperhatikan efek hasil-hasil pada orang-orang di dalam organisasi itu.

4. Orientasi hasil, sejauhmana manajemen memusatkan perhatian pada hasil bukannya pada teknik dan proses yang digunakan untuk mencapai hasil.

5. Orientasi tim, sejauhmana kegiatan kerja diorganisasikan sekitar tim-tim, bukannya induvidu-induvidu.

6. Keagresifan, sejauhmana orang-orang itu agresif dan kompetitif dan bukannya santaisantai.

7. Kemantapan, sejauhmana kegiatan organisasi menekankan dipertahankannya status quo dari pada pertumbuhan.

Sedangkan Riduwan (2005) menyatakan ada 10 (sepuluh) dimensi budaya organisasi yaitu, inisiatif induvidu, toleransi terhadap tindakan, pengarahan, integrasi, dukungan manajemen, kontrol, identitas, sistem imbalan, toleransi konflik dan pola komunikasi.

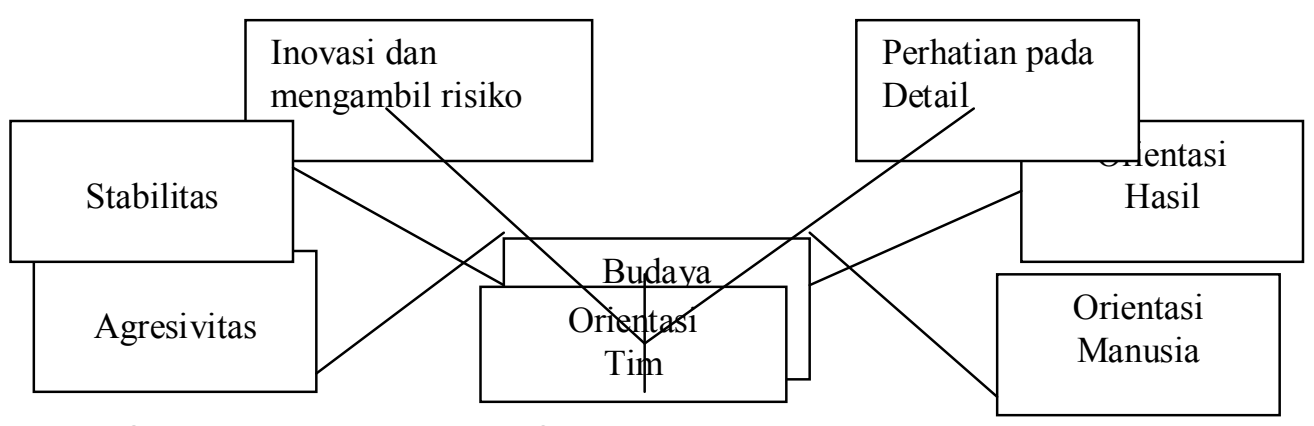

Gambar 1. Dimensi Budaya Organisasi

Sumber : Tunggal (2004)

Tiap karakteristik ini berlangsung pada suatu kontinum dari rendah ke tinggi. maka dengan menilai organisasi itu berdasarkan tujuh karakteristik ini, akan diperoleh gambaran majemuk dari budaya organisasi suatu organisasi.

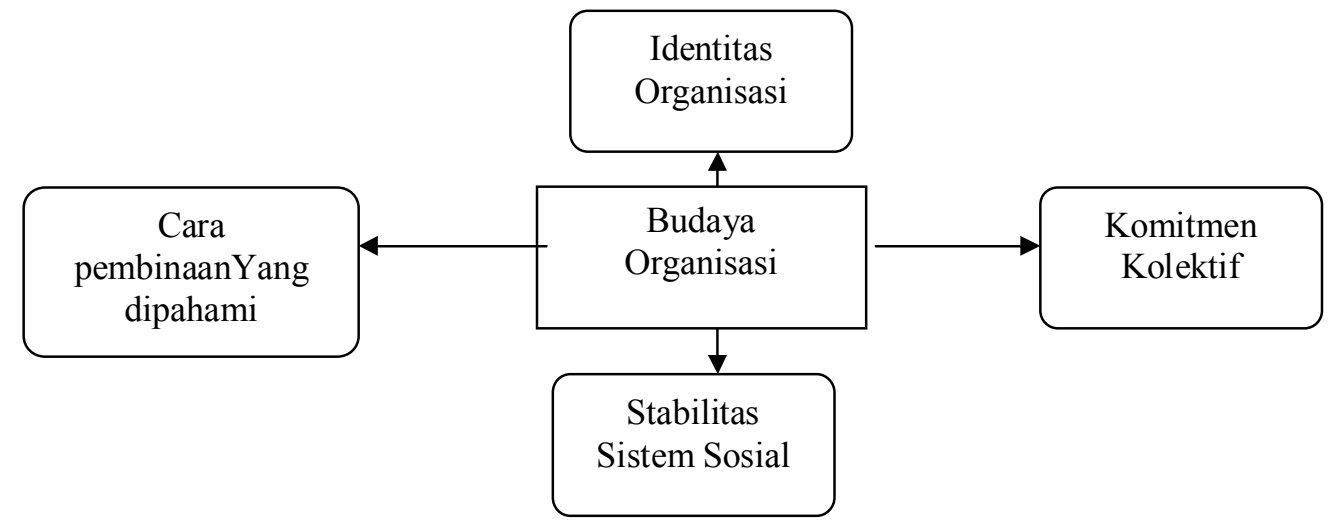

Gambar 2 . Fungsi Budaya Organisasi Kreitner dan Kinicki (2003)

Sedangkan menurut Ndraha (2003) budaya mempunyai beberapa fungsi diantaranya :

1. Sebagai identitas dan citra suatu masyarakat

2. Sebagai pengikat suatu masyarakat 
3. Sebagai sumber inspirasi, kebanggaan, dan sumber daya

4. Sebagai kekuatan penggerak

5. Sebagai kemampuan untuk membentuk nilai tambah

6. Sebagai pola perilaku

7. Sebagai warisan

8. Sebagai substitusi ( pengganti ) formalisasi

9. Sebagai mekanisme adaptasi terhadap perubahan

10. Sebagai proses yang menjadikan bangsa kongruen dengan negara sehingga terbentuk nation - state

Budaya organisasi yang ada diperusahaan sebagai suatu strategi organisasi dibentuk oleh beberapa variabel. Tiap variabel memiliki karakteristik yang unik. Neo dan Mondy dalam loko (2004) mengidentifikasi dua variabel lingkungan yang membentuk dan mempengaruhi efektifitas budaya organisasi dalam suatu organisasi :

1. Faktor-faktor yang berasal dari variabel lingkungan internal perusahaan yaitu :

a. Misi, Visi, rules, dan nilai-nilai yang ditanamkan oleh para pendahulu

b. Nilai-nilai yang ditanamkan secara konkret oleh para pimpinan

c. Komitmen, moral, etika serta suasana kekerabatan dari kelompok kerja

d. Gaya kepemimpinan manajer lini

e. Karakteristik organisasional seperti bentuk dan aktivitas utama, otonomi, dan kompleksitas perusahaan, sistem penghargaan, sistem komunikasi, konflik / kerjasama, serta toleransi terhadap resiko dalam proses administrasi perusahaan.

2. Faktor-faktor yang berasal dari lingkungan global, seperti kecenderungan perubahan ekonomi, tuntutan hukum dan politik, tuntutan social, perkembangan teknologi manufaktur, transfortasi teknologi informasi dan pendukung ekologi.

\section{Kepuasan Kerja}

Pemahaman kepuasan kerja dapat dilihat dengan mengenal istilah dan pengertian kepuasan kerja tersebut. menurut Hasibuan (1995) Kepuasan kerja adalah sikap emosional yang menyenangkan dan mencintai pekerjaannya. Sikap ini dicerminkan oleh moral kerja, kedesiplinan dan prestasi kerja. Sedangkan menurut Robbins (2001) menyatakan : Kepuasan kerja sebagai suatu sikap umum seseorang induvidu terhadap pekerjaannya.

Pada umumnya terdapat banyak teori yang membahas masalah kepuasan seseorang dalam bekerja. Teori-teori kepuasan kerja menurut Mangkunegara (2000) antara lain : 1). Teori Keseimbangan. 2). Teori Perbedaan. 3). Teori Pemenuhan kebutuhan. 4). Teori Pandangan kelompok. 5) Teori Dua faktor Herzberg. 6). Teori Penghargaan

Pernyataan di atas berhubungan dengan rumus dibawah ini :

\section{Valensi $x$ Harapan $=$ Motivasi}

Keterangan :

- Valensi merupakan kekuatan hasrat seseorang untuk mencapai sesuatu

- Harapan merupakan kemungkinan mencapai sesuatu dengan aksi tertentu

- Motivasi merupakan kekuatan dorongan yang mempunyai arah pada tujuan tertentu

\section{Faktor-faktor Kepuasan Kerja}

Kepuasan kerja karyawan terbentuk karena adanya faktor-aktor yang melatarbelakanginya. Seperti kajian teori-teori kepuasan kerja sebelumnya, kepuasan kerja dipengaruhi oleh faktor eksternal dan internal.

Sedangkan menurut Mangkunegara (2000) ada dua faktor yang mempengaruhi kepuasan kerja yaitu :

1. Faktor pegawai, yaitu kecerdasan (IQ) kecakapan khusus, umur, jenis kelamin, kondisi fisik, pendidikan, pengalaman kerja, masa kerja, keperibadian, emosi, cara berfikir. Persepsi dan sikap kerja

2. Faktor pekerjaan, yaitu jenis pekerjaan, struktur organisasi, pangkat, kedudukan, mutu pengawasan, jaminan finansial, kesempatan promosi jabatan, interaksi sosial, dan hubungan kerja.

Berdasarkan pendefenisian mengenai faktor-faktor yang mempengaruhi kepuasan kerja tersebut, tentunya dapat menciptakan suatu suasana yang nyaman bagi karyawan dalam bekerja karena adanya suatu pemenuhan kebutuhan yang menyangkut hak dan keinginan karyawan dalam bekerja. 


\section{METODE}

Dalam mendapatkan data dari penelitian ini menggunakan metode Survey yang tujuannya untuk memperoleh data dalam bentuk kualitatif dan kuantitatf, adapun penelitian ini dititik beratkan dalam kuantitatif.. sedangkan pengumpulan data dilakukan melalui angket, studi dokumen dan wawancar. Adapun menetapkan sample digunakan metode random sampling. Dan metode analisa data yang digunakan adalah uji validitas, uji karelasi produk moment, uji-t dan uji determinasi. Sedangkan pengelolaan data dibantu dengan program SPSS 11.0 for windows. (Singgih Santoso, 2006)

\section{PEMBAHASAN}

Dalam pembahasan ini peneliti menemukan bahwa budaya organisasi memiliki peran yang sangat strategis untuk mendorong dan meningkatkan efektifitas kinerja organisasi, khususnya kinerja karyawan baik dalam jangka pendek maupun jangka panjang. Peran budaya organisasi adalah sebagai alat untuk menentukan arah organisasi, mengarahkan apa yang boleh dan tidak boleh dilakukan, bagaimana mengalokasikan sumber daya organisasinya dan juga sebagai alat untuk menghadapi masalah dan peluang dari lingkungan organisasi.yang mempunyai beberapa fungsi diantaranya : (1) Sebagai identitas dan citra suatu masyarakat. (2) Sebagai pengikat suatu masyarakat. (3) Sebagai sumber inspirasi, kebanggaan, dan sumber daya (4) Sebagai kekuatan penggerak (5) Sebagai kemampuan untuk membentuk nilai tambah (6) Sebagai pola perilaku, (7) ebagai warisan (8) Sebagai substitusi (pengganti) formalisasi, (9) Sebagai mekanisme adaptasi terhadap perubahan, (10) Sebagai proses yang menjadikan bangsa kongruen dengan negara sehingga terbentuk nation-state. Dalam memberikan Kepuasan Kerja kepada karyawan, perusahaan memberikan berupa: (1) Balas jasa yang adil dan layak. (2) Penempatan yang tepat sesuai dengan keahlian (3) Berat ringannya pekerjaan (4) Suasana dan lingkungan pekerjaan (5) Peralatan yang menunjang pelaksanaan pekerjaan. (6) Sikap pimpinan dalam kepemimpinannya semuanya ini merupakan perarutan yang telah ditetapkan oleh Garuda Plaza Hotel Medan.

Dari tabel hasil analisa Uji Validitas dibawah ini yang menggunakan SPSS bila diperhatikan kolom Corrected item total Correlation

1. Nilai- nilai tersebut adalah mengambarkan besarnya $r_{\text {it }}$ dari instrumen penelitian yang akan diuji validitasnya yaitu instrumen varibel $(\mathrm{x})$ Budaya Organisasi dan Variabel $(\mathrm{Y})$ Kepuasan Kerja Karyawan .

2. Bandingkan setiap $r_{\text {it }}$ dari setiap variabel (VAR00001 sampai VAR00010) dengan $r_{\text {tabel }}$ pada $\mathrm{df}=\mathrm{n}-2$ yaitu $\mathrm{df}=61-2=59$ dan $œ=0,05$ maka $\mathrm{r}_{\text {tabel }}=0,254$

3. Nilai $r_{\text {it }}$ yang besarnya $<r_{\text {tabel }}=0,254$ selanjutnya dibuang dan hal ini berarti bahwa butirbutir pertanyaan yang dinyatakan semuanya valid nmerupakan pertanyaan (instrumen) untuk dipergunakan sebagai alat ukur veraibel $(\mathrm{x}$ ) Budaya Organisasi danvariabel $(\mathrm{Y})$ Kepuasan Kerja.

Tabel Hasil Uji Validitas

\begin{tabular}{|c|l|l|l|l|l|}
\hline No & Item & $\begin{array}{c}\text { Varibel } \mathrm{X} \\
\mathrm{r}_{\text {hitung }}\end{array}$ & $\begin{array}{c}\text { Variabel } \\
\mathrm{Y} \text { hitung }\end{array}$ & $\mathrm{t}_{\text {tabel }}$ & Ket \\
\hline 1 & VAR00001 & 0.8660 & 0.7660 & 0.254 & Valid \\
\hline 2 & VAR00002 & 0.8660 & 0.8660 & 0.254 & Valid \\
\hline 3 & VAR00003 & 0.5298 & 0.4298 & 0.254 & Valid \\
\hline 4 & VAR00004 & 0.7544 & 0.5544 & 0.254 & Valid \\
\hline 5 & VAR00005 & 0.6360 & 0.6360 & 0.254 & Valid \\
\hline 6 & VAR00006 & 0.8171 & 0.7171 & 0.254 & Valid \\
\hline 7 & VAR00007 & 0.6376 & 0.6576 & 0.254 & Valid \\
\hline 8 & VAR00008 & 0.8660 & 0.5660 & 0.254 & Valid \\
\hline 9 & VAR00009 & 0.2770 & 0.3770 & 0.254 & Valid \\
\hline 10 & VAR00010 & 0.5445 & 0.4455 & 0.254 & Valid \\
\hline
\end{tabular}

Untuk menguji hipotesa penulis menggunakan analisa product moment, sehingga dapat diketahui ada tidaknya hubungan antara variabel $x$ dan varabel $y$ dengan rumus: uji korelasi produk moment : 


$$
\begin{aligned}
& r_{x y}=\frac{61(130913)-(2810)(2818)}{\sqrt{61(131542)-(2810)^{2} \cdot 61(131730)-(2818)^{2}}} \\
& r_{x y}=\frac{7985693-7918580}{\sqrt{8024062-7896100.8035530-7941124}} \\
& r_{x y}=\frac{67113}{\sqrt{127962.94406}} \\
& r_{x y}=\frac{67113}{\sqrt{12080380572}} \\
& r_{x y}=\frac{67113}{109910,7846} \\
& r_{x y}=0,611
\end{aligned}
$$

Berdasarkan hasil perhitungan di atas nilai koefisien karelasi sebesar 0,611 apabila di konsultasikan pada tabel menyatakan bahwa adanya hubungan yang tinggi antara variabel $x$ (Budaya organisasi) dengan varaibel y (Kepuasan Kerja karyawan) jadi dengan kata lain hubungan tersebut tinggi dan positif.

Uji $\boldsymbol{t}$

Untuk membuktikan ada tidaknya pengaruh tersebut secara nyata (signifikan), sekaligus membuktikan hipostesa yang telah di ajukan, maka di lakukan uji hipotesa terhadap nilai koefisien korelasi di atas digunakan rumus :

$$
\begin{aligned}
t & =\frac{0,611 \sqrt{61-2}}{\sqrt{1-0,611^{2}}} \\
t & =\frac{0,611(7,68)}{\sqrt{0,63}} \\
t & =\frac{4,69}{0,79} \\
& =5,94
\end{aligned}
$$

Kemudian untuk menentukan besar $t_{\text {tabel }}$ maka terlebih dahulu di tentukan $t \propto$ yaitu $5 \% \quad(0,05)$ karena penelitian ini ada 2 ujung maka $\mathrm{t} œ=\mathrm{t} 1 / 2 œ$, jadi $\mathrm{t} \propto$ nya adalah 0,025 . Kemudian ditentukan df nya dengan rumus : $\mathrm{df}=\mathrm{n}-2 \mathrm{df}=61-2=59$, maka nilai $t_{\text {tabel }}$ adalah 2.000 , dari hasil perhitungan diperoleh $t_{0}=5,94$ dan $t_{\text {tabel }}=2,000$ oleh karena hasil perhitungannya $t_{0}>t_{\text {tabel }}$, dengan demikian $\mathrm{H}_{0}$ ditolak pada tingkat signifikansi $5 \%$ yang berarti bahwa ada pengaruh antara insentif dengan kinerja karyawan.

Untuk lebih jelasnya pengaruh tersebut dapat dilihat dari uji t determinasi dengan rumus, yaitu :

$\mathrm{D}=\mathrm{r}^{2} \times 100 \%$.

$$
\begin{gathered}
D=(0.611)^{2} \times 100 \% \\
=0,3733 \times 100 \% \\
=37,33 \%
\end{gathered}
$$

Dari perhitungan di atas maka dapat dilihat bahwa pengaruh budaya organisasi terhadap kepuasan kerja karyawan sebesar $37.33 \%$. Sedangkan $62.67 \%$ dipengaruhi oleh faktor-faktor lain. 


\section{REFERENCES}

Arikunto, Suharsini, 1996, Metodelogi Penelitian, Renika Cipta, Jakarta

David, Fred, R, 2004, Manajemen Strategi, Konsep, Edisi Ketujuh, Ahli Bahasa Alexander Sindoro, Prehallindo, Jakarta

Hasibuan, Malayu S.P, 2000, Manajemen Sumber Daya Manusia, Edisi Revisi, Cetakan Kedua, Bumi Aksara, Jakarta

Hidayat, R. (2009). Penerapan Sistem Informasi Manajemen sebagai Alat Pelaksanaan Sistem Administrasi Akademik. JURIDIKTI: Jurnal IImiah Pendidikan Tinggi, 2(2), 56-59.

Hidayat, R. (2010). Analisis Tingkat Penggunaan Internet Dikalangan Mahasiswa dan Hubungannya dalam Peningkatan Nilai Akademik (Studi Kasus pada Mahasiswa di Kota Medan). Jurnal Mediasi, 2(2), 55-63.

Kreitner, Robert dan Kinicki, Angelo, 2003, Perilaku Organisasi, Terjemahan Erly Suiandy, Edisi Pertama, Salemba Empat, Jakarta

Loko, Andreas, 20014, Kepemimpinan dan Kinerja Organisasi, Isu, Teori dan Solusi, Cetakan Pertama, Aara Books, Yokyakarta

Mangkunegara, AA, Anwar Orabu, 2000, Manajemen Sumber Daya Manusia Perusahaan, Remaja Rosdakarya, Bandung

Robbins, Stephen P, 2000, Perilaku Organisasi, Konsep, Kontroversi, Aplikasi, Jilid II, Ahli Bahasa Hadyana Pujaatmaka dan Benyamin Molaan, Presnhallindo, Jakarta

Sugiono, 1994, Metode Penelitian, Renika Cipta, Jakarta

Supriyanto, \& Hidayat, R. (2010). Rancangan Sistem Informasi Administrasi Akademik berbasis Komputer. JURIDIKTI: Jurnal IImiah Pendidikan Tinggi, 3(3), 147-157

Tunggal, Amin Widjaja, 2004, Tanya Jawab Budaya Organisasi (Organizational Culture), Harvarindo, Jakarta 